\title{
INTERNET LITERACY: AN ANALYSIS ON ITS POSSIBILITY
}

\author{
Maria Purnawati (maria.p@unikama.ac.id) \\ Uun Muhaji (uun.muhaji@gmail.com) \\ Riza Weganofa (rizaweganofa@ unikama.ac.id) \\ English Education Department, Universitas Kanjuruhan Malang
}

\begin{abstract}
As technology emerges so fast and the demands of curriculum to integrate technology and innovation into classrooms, teachers are pushed to penetrate technology and bring the internet to everyday talks with the students. In accordance, using the euphoria of digital natives, students are also pushed to absorb and adjust themselves to growth of technology. In turn, there is no specific course on the use of the internet like the 90s curriculum had in the university level. However, the fact that not so many students bring laptop to campus everyday might indicate that they did not use the internet for learning outside classroom intensively. This study aims at describing how much internet literacy that students have. After analyzing the questionnaire descriptively, it was found that the participants of this study had poor internet literacy, in terms of the use of email, the use of social media, and the use of English in social media.
\end{abstract}

Keywords: internet literacy, descriptive, poor category

\section{Background of Study}

To accommodate the demands of the growing of technology and knowledge on education, a study program has to go along with this. Generally people can see whether a certain study program accommodate this challenge or not through the curriculum presented. Thus, English Department of Universitas Kanjuruhan Malang has determined its vision to be a leading study program in teaching material development based on IPTEKS (technology and knowledge) in order to produce competitive graduates in 2025. This vision literally describes that the curriculum offered is based on the growing technology and education.

Selber in Johnson (2007) defines literacy is not only merely the ability to read and write, but it covers the ability to use technology. Internet is now a happening technology that almost todays' learners opt to it. Further, todays' learners are claimed to be millennial generation in which they grow up surrounded by 2.0 technology. This was strengthen by Presky (in Liu:2010) who attributed todays' students as digital natives, because they spend almost their lives surrounded by computer, video games, iPod, smart phones, and other devices.

Several experts might define internet literacy differently. Colwell, Hunt-Barron and Reinking (2013) mention that digital literacy covers the ability to seek for and evaluate any information provided by the internet. Meanwhile, Semas in Johnson (2003) prefer the term internet literacy to specifically refer to the ability to seek for online information. Further, Hofstetter in Johnson (2003) provides detailed definition of internet literacy, such as the ability to connect, secure, communicate, use multimedia, and do web development. Walker and White (2013) also add that it is a need for todays' students to comprehend digital competence. There are four elements that should be comprehended: procedure competence, socio-digital, digital discourse, and strategic competence. 
It can be concluded that internet literacy is not solely defined as the ability to send an email or simply use a search engine. However, it should be defined as the ability to seek for, use, evaluate, and develop information provided for self enrichment.

This internet literacy should be ideally taught at school, including university. As most of people assume that todays' students are already acquainted with computer and internet, knowledge on how to use this digital technology for learning effectively is no longer in the curriculum. This study is derived from the fact that most of students in University of Kanjuruhan Malang come from East of Indonesia, such as Ende, Adonara, Manggarai, Sumba, West Kalimantan, West Papua, and a small number comes from East Java. These students have different cultures, customs, and characters with the lecturers who most of them are from Java. There have been no recent studies about the impact of different internet accessibility got by students from Java and East Indonesia. The fact that not all students bring any laptop or have smartphone with internet facility to class everyday indicate that they are rarely use internet to for learning outside classroom.

This study aims at describing how much students' internet literacy, specifically students in English Education Department. It also reveals the most commonly web visited by the students. Most universities in Indonesia and also many public places facilitate its students and society with free connection. This is done to support open access of information for everyone. Todays' millennial generation are exposed to kinds of social media massively. The fact that English is regarded as a foreign language for Indonesia students brings another angle of the use of internet for English learning. Thus, lecturers might know how to adjust the materials if they want to integrate the use of internet in the classroom, also they know how to penetrate internet for learning. Based on the background of the study described, the question of this study is formulated into: "How much internet literacy that students of English Education Department have?"

The findings of this study discuss how much internet literacy that students of English Education Department have regardless the sex and age differences. Johnson (2007) mentions four activity categories that users do with internet, communication, information, entertainment, and advertisement and online shopping. Hoffstetter in Johnson (2007) adds another category, which is technical ability, such as security, download, and connection. This discussion in this study covers categories suggested by Johnson, excluding technical ability.

\section{Research Method}

This study implements qualitative approach to solve the problem stated. Qualitative approach was taken because it tries to describe the phenomenon of a certain event. In this study, the researcher tries to describe how much internet literacy that students of English department have. The participant involved in this study was the third year students of English Education Department of Universitas Kanjuruhan Malang. There were 36 students voluntarily involved in this study. These students were chosen because they, especially those who came from East Indonesia, have spent enough time in Java and got equal access towards internet facility like those who came from Java.

The main instrument in this study was the researchers themselves, further, the researchers used questionnaire as minor instrument to measure students' internet literacy. The questionnaire was divided into four parts: the use of email for eligible 
communication, the use of social media, the use of English in their social media, and the use of English in daily communication. After collecting students' questionnaires, the researchers analyzed them descriptively.

\section{Result and Discussion}

The questionnaire was used to measure how much internet literacy that the participants have, and specifically how far the use the internet for learning English. The questionnaire was divided into two forms. The first was in scale form, which range from Strongly Agree, Agree, Disagree, and Strongly Disagree. Meanwhile, the second form was a short essay question, asking about students' most visited sites and the most distracting things from the internet.

When the students were asked about their email address, all of them acknowledged that they have an email address. However, how they used the email address might show a surprising fact (Table 1). Table 1 shows that most of the participants did not use email for their correspondences, although they agreed that they used email for academic purpose, it might happen because the lecturers assigned them to send homework through email. They certainly have a low frequency of checking emails. They rather chose another media for communicating, such as using social media, which is assumed to be more practical. One good reason for having an email address for the participants was they needed it for signing up to social media, online shopping accounts, game online, and other applications.

Table 1. The use of email

\begin{tabular}{|c|c|c|c|c|}
\hline & Frequency & $\begin{array}{l}\text { Mean } \\
\text { Score }\end{array}$ & $\begin{array}{l}\text { Internet } \\
\text { Category }\end{array}$ & Literacy \\
\hline Using email for correspondence & 85 & 2.36 & Poor & \\
\hline $\begin{array}{l}\text { Using email for academic } \\
\text { purpose }\end{array}$ & 105 & 2.91 & Poor & \\
\hline Frequency of checking email & 89 & 2.47 & Poor & \\
\hline
\end{tabular}

Although it was found that the participants of this study had a low frequency of checking their emails, they certainly spend a plenty of time checking their social media when they were connected to the internet. They $100 \%$ admitted that they have at least one social media and became an active user of it with the mean score of it was 3.58 (Table 2).

Table 2. The use of social media

\begin{tabular}{|c|c|c|c|}
\hline & Frequency & $\begin{array}{l}\text { Mean } \\
\text { Score }\end{array}$ & $\begin{array}{l}\text { Internet Literacy } \\
\text { Category }\end{array}$ \\
\hline Frequency of checking social media & 129 & 3.58 & Strong \\
\hline Using social media for academic purpose & 137 & 3.81 & Strong \\
\hline $\begin{array}{l}\text { Frequency of checking social media for } \\
\text { academic purpose }\end{array}$ & 113 & 3.14 & Strong \\
\hline Using social media for friendship & 137 & 3.81 & Strong \\
\hline Frequency of checking social media for & 118 & 3.28 & Strong \\
\hline
\end{tabular}


Using social media for advertisement and 129 online shopping

Frequency of checking social media for 98 advertisement and online shopping
3.58 Strong

$2.72 \quad$ Poor

Apparently Table 2 pictures that checking social media, either for academic purpose, friendship, or advertisement and online shopping is favorable. The needs to engage and keep in touch with family or friends might be one of the reasons of this phenomenon. As most of the participants are coming from outside Malang, even Java, strengthens this reason. The more sophisticated features offered by some social media, such as phone call, video call, live streaming, which in turn suggested in cost efficiency, becomes another point to the use of social media.

The last section of the questionnaire that the researchers ask was about whether the participant used English in communicating using social media. Interestingly, most of the participants (28 out of 36 students) argued that they joined a group which used English as the medium to communicate (Table 3). However, most of them were silent readers and rarely checked their group.

Table 3. The use of English in Social Media

\begin{tabular}{|c|c|c|c|c|}
\hline & Frequency & $\begin{array}{l}\text { Mean } \\
\text { Score }\end{array}$ & $\begin{array}{l}\text { Internet } \\
\text { Category }\end{array}$ & Literacy \\
\hline $\begin{array}{l}\text { Joining English group in social } \\
\text { media }\end{array}$ & 120 & 3.33 & Strong & \\
\hline $\begin{array}{l}\text { Frequency of checking group which } \\
\text { uses English }\end{array}$ & 82 & 2.27 & Poor & \\
\hline $\begin{array}{l}\text { Actively participate in group which } \\
\text { uses English }\end{array}$ & 60 & 1.67 & Very Poor & \\
\hline
\end{tabular}

Thus, for those three sections (the use of email, the use of social media, and the use of English in social media), the researchers found that students' internet literacy is poor (Table 4). Also, Table 4 showcases that the participants of this current study have strong internet literacy in term of the use of social media. Unfortunately the participants did not use the internet, especially social media as a way to learn English maximally.

Table 4. Students' Internet Literacy

\begin{tabular}{lllll}
\hline & Frequency & $\begin{array}{l}\text { Mean } \\
\text { Score }\end{array}$ & $\begin{array}{l}\text { Internet } \\
\text { Category }\end{array}$ & Literacy \\
\hline $\begin{array}{l}\text { The use of email } \\
\text { The use of social media }\end{array}$ & 279 & 2.59 & Poor \\
$\begin{array}{l}\text { The use of English in social } \\
\text { media }\end{array}$ & 262 & 3.42 & Strong \\
Total & 1402 & 2.43 & Poor \\
\hline
\end{tabular}

The finding is confirmed by the fact that most of the participants confessed that they use the internet to browse online dictionary, such as Webster, Oxford, and others, and some of them used Google Translate, and Wikipedia. Few of them mentioned the 
use of other sites, such as reputable journals, BBC Online learning, and English learning forum. Further, the participants argued that sometimes they did not like browse the internet because of pop-up advertisement, pornography contents, and viruses.

\section{Conclusion}

People may not generalize that todays' students definitely have strong internet literacy. The participants of this study are categorized having poor internet literacy, in term of the use of email, the use of social media, and the use of English in social media. Although they showed strong internet literacy in term the use of social media, they could not take of advantage of this to help them learning English. The next researchers are expected to investigate the other category of internet literacy as suggested by Hoffestter, such as technical ability, covering security, download, and reproduce.

\section{References}

Colwell, J., Hunt-Barron, S., D. Reinking. (2013). Obstacles to Developing Digital Literacy on the Internet in Middle School Science Instruction. Journal of Literacy Research 45(3) 295 -324. Online. DOI: 10.1177/1086296X13493273, diakses pada 19 Februari 2017.

Johnson, G.M. (2007). Functional Internet Literacy: Required Cognitive Skills with Implications for Instruction. E-Learning Volume 4, Number 4, 2007. Online. www.wwwords.co.uk/ELEA

Liu, Y. (2010). Social media tools as a learning resource. Journal of Educational Technology Development and Exchange, 3(1), 101-114.Online http://sicet.org/journals/jetde/jetde10/8-Liu.pdf, diakses pada 15 April 2015.

Walker, A \& White, G. (2013). Technology Enhanced Language Learning: Connecting Theory and Practice. Cambridge: Cambridge University. 